\title{
Rare Genetic Forms of Obesity: Clinical Approach and Current Treatments in 2016
}

\author{
Hélène Huvenne ${ }^{a, b, c} \quad$ Béatrice Dubern ${ }^{b, c, d}$ Karine Clément ${ }^{b, c, e}$ \\ Christine Poitou ${ }^{b, c, e}$
}

${ }^{a}$ GHICL, Saint-Vincent de Paul Hospital, Department of Pediatrics, Lille, France; ${ }^{b}$ INSERM, Nutriomics UMR_S U1166, University Pierre et Marie Curie-Paris 6, Paris, France; ' Institute of Cardiometabolism and Nutrition, ICAN, Pitié-Salpêtrière Hospital, Paris, France; dDepartment of Pediatric Nutrition and Gastroenterology, Armand-Trousseau Hospital, Assistance Publique-Hôpitaux de Paris, Paris, France; e Nutrition Department, French Reference Centre for Prader-Willi Syndrome, Pitié-Salpêtrière Hospital, Assistance Publique-Hôpitaux de Paris, Paris, France

\section{Key Words}

Obesity · Genetics · Leptin-melanocortin pathway · Bariatric surgery · Whole-exome sequencing

\section{Abstract}

Obesity results from a synergistic relationship between genes and the environment. The phenotypic expression of genetic factors involved in obesity is variable, allowing to distinguish several clinical pictures of obesity. Monogenic obesity is described as rare and severe earlyonset obesity with abnormal feeding behavior and endocrine disorders. This is mainly due to autosomal recessive mutations in genes of the leptin-melanocortin pathway which plays a key role in the hypothalamic control of food intake. Melanocortin 4 receptor(MC4R)-linked obesity is characterized by the variable severity of obesity and no notable additional phenotypes. Mutations in the MC4R gene are involved in 2-3\% of obese children and adults; the majority of these are heterozygous. Syndromic obesity is associated with mental retardation, dysmorphic features, and organ-specific developmental abnormalities. Additional genes participating in the development of hypothalamus and central nervous system have been regularly identified. But to date, not all involved genes have been identified so far. New diagnostic tools, such as whole-exome sequencing, will probably help to identify other genes. Managing these patients is challenging. Indeed, specific treatments are available only for specific types of monogenic obesity, such as leptin deficiency. Data on bariatric surgery are limited and controversial. New molecules acting on the leptin-melanocortin pathway are currently being developed. 
Huvenne et al.: Rare Genetic Forms of Obesity: Clinical Approach and Current Treatments in 2016

\section{Introduction}

Obesity, defined as an excess of fat mass with an impact on physical health, is a complex and multifactorial disease. It is a public health concern, and the World Health Organization estimates that 1.9 billion adults are overweight $\left(\mathrm{BMI}>25 \mathrm{~kg} / \mathrm{m}^{2}\right)$, among which 600 million are obese (BMI $>30 \mathrm{~kg} / \mathrm{m}^{2}$ ). Also, in children, the worldwide prevalence of overweight and obesity increased from $4.2 \%$ in 1990 to $6.7 \%$ in 2010 but has stabilized in recent years [1]. Obesity results from the interaction of genetic factors with numerous environmental factors (such as overeating and/or reduction of physical activity). The comprehension of the molecular mechanisms of obesity progressed enormously in the last years thanks to the development of faster and more precise genetic screening tools applied in cohort studies or in examinations with focus on subjects and their families. In particular, whole-exome sequencing showed its power to identify new syndromes associated with obesity or new forms of obesity due to a single naturally occurring dysfunctional gene (i.e. monogenic obesity).

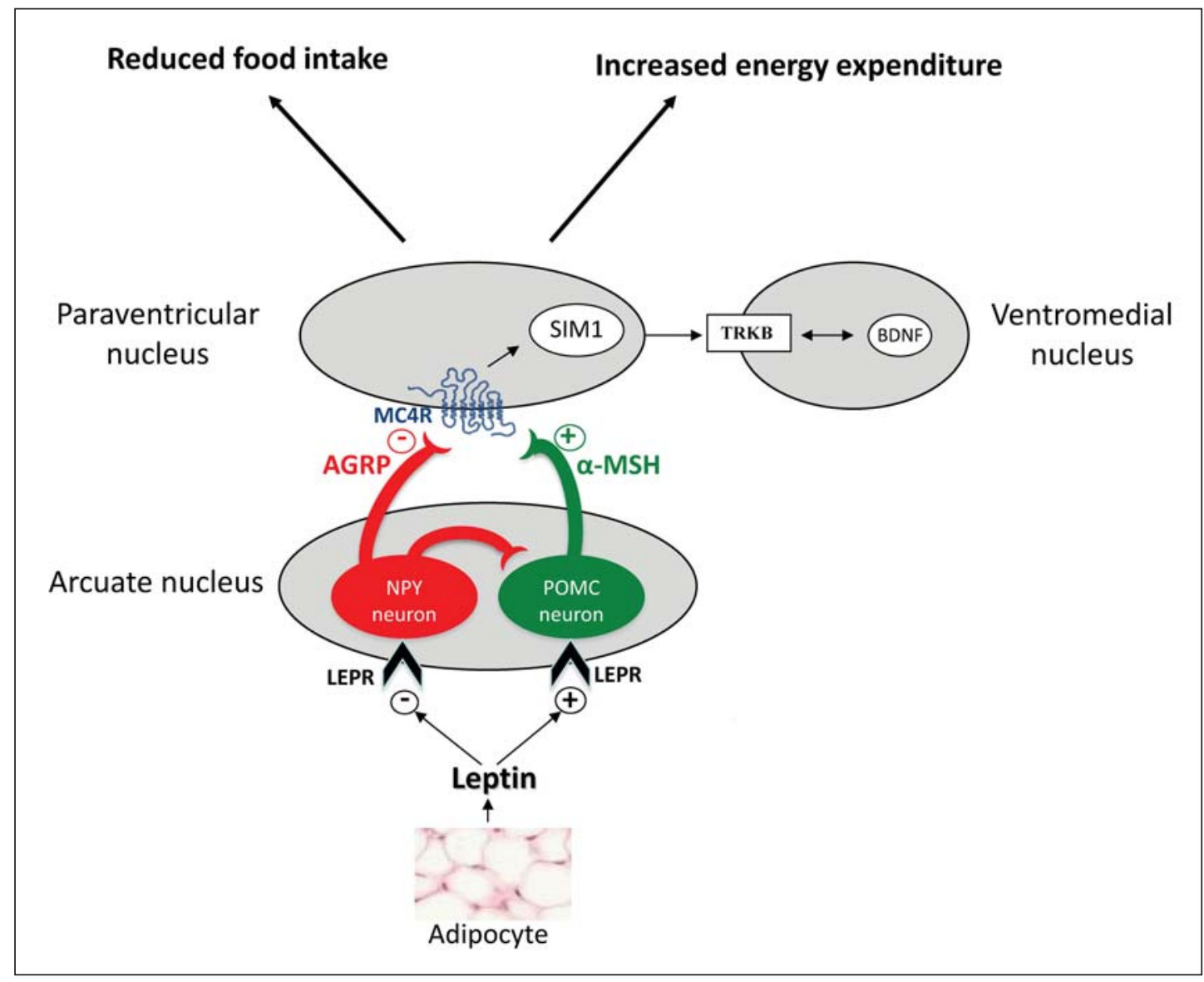

Fig. 1. The leptin/melanocortin pathway. POMC neurons in the arcuate nucleus are activated by leptin and produce the $\alpha$-melanocyte stimulating hormone $(\alpha-\mathrm{MSH})$, which then activates the MC4R receptor in the paraventricular nucleus resulting in a satiety signal. A separate group of neurons expressing NPY and AGRP produce molecules that act as potent inhibitors of MC4R signaling. The downstream roles of SIM1, BDNF, and TKRB are currently being explored. AGRP = agouti-related protein; BDNF = brain-derived neurotropic factor; LEPR = leptin receptor; NPY = neuropeptide Y; POMC = proopiomelanocortin; SIM1 = single-minded 1; TRKB $=$ tyrosine kinase receptor. 
Huvenne et al.: Rare Genetic Forms of Obesity: Clinical Approach and Current Treatments in 2016

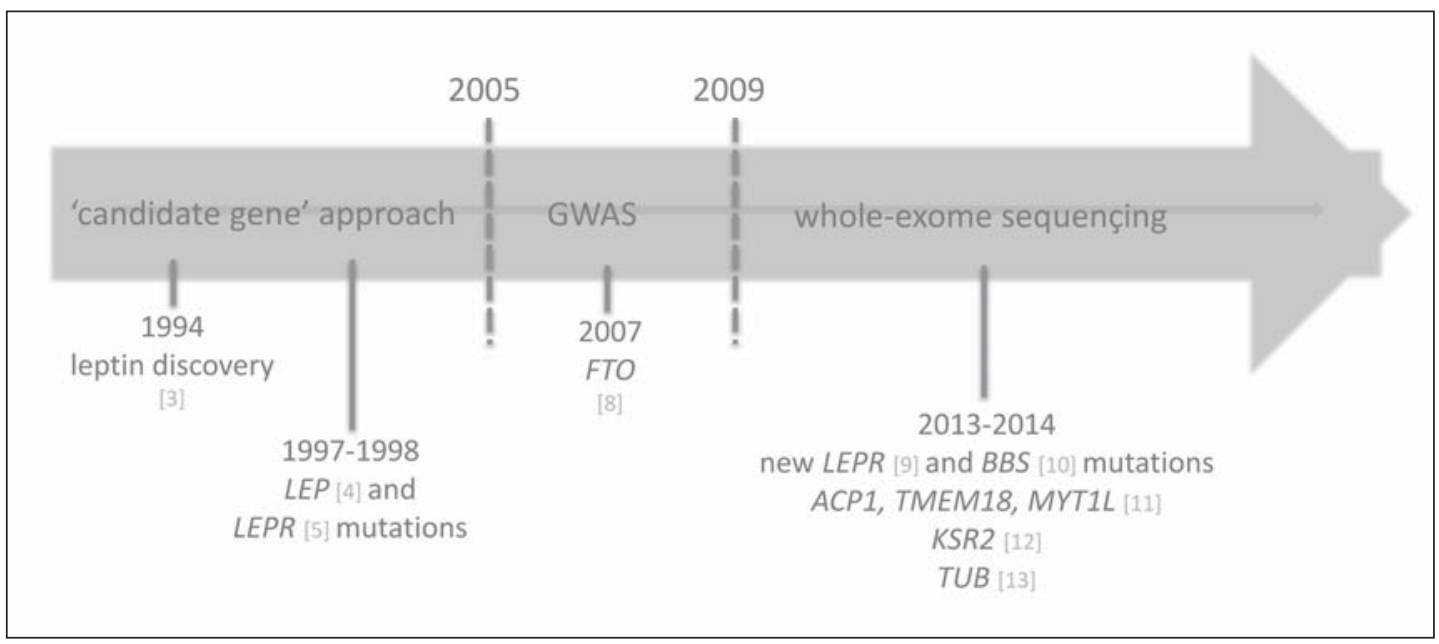

Fig. 2. Historical steps leading to the discovery of genetic mutations in obesity. ACP1 = acid phosphatase 1, soluble; BBS = Bardet-Biedl syndrome; FTO = fat mass and obesity; GWAS = genome wide scan association study; KSR2 = kinase suppressor of Ras 2; LEP = leptin; LEPR = leptin receptor; MYT1L = myelin transcription factor 1-like; TMEM18 = transmembrane protein 18; TUB = tubby bipartite transcription factor.

Several clinical presentations are described in obesity depending on the genes involved:

- Monogenic obesity is described as rare and severe early-onset obesity associated with endocrine disorders. The impact of genetics is high and only little dependent on environmental factors. This form of obesity is mainly due to mutations in genes of the leptin/melanocortin axis (fig. 1) involved in food intake regulation (genes of leptin $(L E P)$ and leptin receptor ( $L E P R)$, proopiomelanocortin $(P O M C)$, proconvertase 1 $(P C 1))$ or in specific genes linked to these pathways. New mutations were identified in the past few years.

- Syndromic obesity corresponds to severe obesity associated with additional phenotypes (mental retardation, dysmorphic features, and organ-specific developmental abnormalities). Prader-Willi (PWS) and Bardet-Biedl (BBS) syndromes are the 2 syndromes most frequently linked to obesity, but more than 100 syndromes are now associated with obesity.

- Oligogenic obesity, such as melanocortin 4 receptor(MC4R)-linked obesity, is characterized by a variable severity of obesity, partly dependent on environmental factors and the absence of a specific phenotype. This type of obesity is responsible for $2-3 \%$ of obesity in adults and children.

These rare forms of obesity distinguish themselves from the polygenic obesity, which is the most common clinical presentation. Here, each susceptibility gene considered individually would only have a slight effect on weight. The cumulative contribution of these genes would be amplified by an 'obesogenic' lifestyle (such as overfeeding, sedentary living, stress, etc.) [2]. This presentation of obesity will not be elaborated further in this review.

Rare genetic forms of obesity are important to be detected clinically because it allows to progress in understanding the physiopathology of obesity. On the other hand there is a specific management of these forms of obesity provided by specialized and multidisciplinary teams. Thus, this article aims to give an updated summary of genetic forms of obesity and their available therapeutic options, including bariatric surgery, for clinical care specialists occupied in the obesity field. 
Huvenne et al.: Rare Genetic Forms of Obesity: Clinical Approach and Current

Treatments in 2016

Table 1. Rare monogenic forms of human obesity

\begin{tabular}{|c|c|c|c|c|}
\hline Gene & Mutation type & Prevalence & Obesity & Associated phenotypes \\
\hline Leptin & Homozygous mutation & $\begin{array}{l}\text { Diagnosed in fewer } \\
\text { than } 100 \text { patients } \\
\text { worldwide }\end{array}$ & $\begin{array}{l}\text { Severe, from the } \\
\text { first days of life }\end{array}$ & $\begin{array}{l}\text { Gonadotropic and thyrotropic insufficiency } \\
\text { Alteration in immune function }\end{array}$ \\
\hline LEPR & Homozygous mutation & $\begin{array}{l}2-3 \% \text { of patients } \\
\text { with severe early- } \\
\text { onset obesity }\end{array}$ & $\begin{array}{l}\text { Severe, from the } \\
\text { first days of life }\end{array}$ & $\begin{array}{l}\text { Gonadotropic, thyrotropic and somatotropic } \\
\text { insufficiency } \\
\text { Alteration in immune function }\end{array}$ \\
\hline POMC & $\begin{array}{l}\text { Homozygous or } \\
\text { compound heterozygous }\end{array}$ & $\begin{array}{l}\text { Diagnosed in fewer } \\
\text { than } 10 \text { patients } \\
\text { worldwide }\end{array}$ & $\begin{array}{l}\text { Severe, from the } \\
\text { first months of } \\
\text { life }\end{array}$ & $\begin{array}{l}\text { ACTH insufficiency } \\
\text { Mild hypothyroidism and ginger hair if the } \\
\text { mutation leads to the absence of POMC } \\
\text { production }\end{array}$ \\
\hline PCSK1 & $\begin{array}{l}\text { Homozygous or } \\
\text { compound heterozygous }\end{array}$ & $\begin{array}{l}\text { Diagnosed in fewer } \\
\text { than } 20 \text { patients } \\
\text { worldwide }\end{array}$ & $\begin{array}{l}\text { Severe obesity } \\
\text { occurring in } \\
\text { childhood }\end{array}$ & $\begin{array}{l}\text { Adrenal, gonadotropic, somatotropic and } \\
\text { thyrotropic insufficiency } \\
\text { Postprandial hypoglycemic malaises } \\
\text { Severe malabsorptive neonatal diarrhea } \\
\text { Central diabetes insipidus }\end{array}$ \\
\hline SIM1 & $\begin{array}{l}\text { Translocation between } \\
\text { chr } 1 \mathrm{p} 22.1 \text { and } 6 \mathrm{q} 16.2 \\
\text { in the SIM1 gene }\end{array}$ & $\begin{array}{l}\text { Diagnosed in fewer } \\
\text { than } 50 \text { patients } \\
\text { worldwide }\end{array}$ & $\begin{array}{l}\text { Severe obesity } \\
\text { occurring in } \\
\text { childhood }\end{array}$ & $\begin{array}{l}\text { Inconstantly, neurobehavioral abnormalities } \\
\text { (including emotional lability or autism-like } \\
\text { behavior) }\end{array}$ \\
\hline NTRK2 & $\begin{array}{l}\text { De novo heterozygous } \\
\text { mutation }\end{array}$ & $\begin{array}{l}\text { Diagnosed in fewer } \\
\text { than } 10 \text { patients } \\
\text { worldwide }\end{array}$ & $\begin{array}{l}\text { Severe obesity } \\
\text { from the first } \\
\text { months of life }\end{array}$ & $\begin{array}{l}\text { Developmental delay } \\
\text { Behavioral disturbance } \\
\text { Blunted response to pain }\end{array}$ \\
\hline
\end{tabular}

\section{Evaluation of Strategies in Genetic Explorations of Obese Cases}

Different molecular strategies were used to determine the genetic factors involved in obesity (fig. 2). The 'candidate gene' approach was one of the first and allowed, in association with the precise clinical analysis of subjects presenting with early-onset extreme obesity (prior to 6 years of age), to define rare monogenic forms of obesity (table 1). The highlighted genetic anomalies affect key factors related to the leptin-melanocortin pathway, which are known to be pivotal in energy balance regulation (fig. 1) [4-7].

Since 2005, the genome-wide association study (GWAS) has made it possible to identify 119 independent loci associated with BMI and common obesity status in large populations [8]. Among these, the most replicated gene was the FTO (fat mass and obesity) gene in obese children and adults [9]. Interestingly, the GWAS showed that almost all genes involved in monogenic and oligogenic forms of obesity ( $L E P R, P O M C, M C 4 R, P C 1)$ display common variants associated with BMI and polygenic obesity as well [8].

Recently, faster, more precise and effective genetic screening tools, such as whole-exome sequencing, have been developed. Whole-exome sequencing allowed identifying mutations responsible for rare genetic diseases in a small number of affected subjects. In genetic obesity, it notably revealed 2 novel homozygous $L E P R$ mutations [10] and 5 novel mutations in BBS genes [11]. In case of BBS, this approach confirmed the importance of genes involved in the functioning of the primary cilium. It highlighted that dysfunction in primary cilia can be responsible for various metabolic defects and particularly plays a role in energy homeostasis dysregulation leading to severe obesity. This method was also helpful to identify new variants and mutations in patients with syndromic obesity [12-17]. For example, it demonstrated a 
Huvenne et al.: Rare Genetic Forms of Obesity: Clinical Approach and Current Treatments in 2016

paternal deletion, encompassing the ACP1 (acid phosphatase 1), TMEM18 (transmembrane protein 18), and MYT1L (myelin transcription factor 1-like) genes, in 5 unrelated patients presenting with severe early-onset obesity, intellectual deficiency, and severe behavioral difficulties [12]. It also enabled to identify multiple rare variants in the KSR2 (kinase supressor of Ras 2) gene in 45 unrelated individuals presenting with a low heart rate, reduced basal metabolic rate, and severe insulin resistance in addition to severe obesity [13]. A homozygous frameshift mutation in the TUB (tubby-like protein) gene was also identified using wholeexome sequencing in a proband who presented with obesity, night blindness, decreased visual acuity, and electrophysiological features of a rod-cone dystrophy [14] (table 2). Exome sequencing also revealed a mutation of the CPE (carboxypeptidase E) gene in a morbidly obese woman with intellectual disability, type 2 diabetes mellitus, and hypogonadotropic hypogonadism [15], and it showed a mutation of the RAI1 (retinoic acid-induced 1) gene in a child with morbid early-onset obesity, hypoventilation, and autonomic and behavioral disturbances [16].

\section{Clinical Phenotypes}

The most frequent forms of syndromic obesity are PWS and BBS (table 2).

The PWS (1 in 20,000-25,000 births) is characterized by severe neonatal hypotonia, eating disorders evolving in several phases (from anorexia with sucking disorders in the first months of life to hyperphagia with major food impulsiveness at about 4-8 years of age) [18], body composition abnormalities [19], endocrine anomalies (growth hormone (GH) deficiency, hypogonadism), variable intellectual deficiency, behavioral difficulties, and dysmorphy [20]. This syndrome is due to the physical or functional absence of the paternal chromosomal segment 15q11-q13. At least 5 genes, located in the PWS chromosomal region and expressed in the hypothalamus, have been identified, but their functions have not yet been understood completely: MRKN3 (makorin 3), MAGEL2 (MAGE-like 2), NDN (necdin), NPAP1 (nuclear pore associated protein 1), SNURF-SNRPN (SNRPN upstream reading frame - small nuclear ribonucleoprotein polypeptide $\mathrm{N})[21,22]$. The exact mechanisms by which these genes contribute to the development of early-onset obesity are still to be defined. Several other unknown genes are probably mutated, and this could explain the variability of PWS phenotype.

BBS is a highly heterogeneous disease. It is characterized by severe early-onset obesity, retinal dystrophy, malformed extremities (syndactyly, polydactyly), kidney diseases, hypogonadism, dysmorphy, and eventually mental disabilities. At least 19 different genes are implicated in the BBS, but all are involved in primary cilium function [23]. Consequently, BBS is now defined as a ciliopathy (primary cilium dysfunction) [24]. The specific mechanisms leading to obesity in BBS are still to be elucidated. Several hypotheses were suggested. In the first place, the hypothesis of a central origin of obesity due to hypothalamic dysfunction and leptin resistance associated with hyperphagia was developed. BBS proteins are, in particular, required for LEPR localization in the hypothalamus [23]. Other hypotheses of a peripheral origin from adipose tissue and adipocyte proliferation or other endocrine tissues (pancreas, stomach, intestine) were also proposed [25].

Additional rare syndromic forms of obesity are presented in table 2.

Mutations in human genes encoding for leptin [4], LEPR [5], POMC [6], and PC1 [7] lead to severe obesity occurring soon after birth (table 1). Patients carrying mutations show a rapid and very early important increase in weight, as illustrated by the weight curve of LEPRdeficient subjects [26]. Feeding behavior is mainly characterized by major hyperphagia and ravenous hunger [27]. But, surprisingly, a leptin-deficient Austrian girl has been detected with more moderate obesity (BMI $31.5 \mathrm{~kg} / \mathrm{m}^{2}$ ) and extremely low daily calorie intake in 
Huvenne et al.: Rare Genetic Forms of Obesity: Clinical Approach and Current

Treatments in 2016

Table 2. Main syndromic forms of obesity

\begin{tabular}{|c|c|c|c|}
\hline Syndrome & Clinical features in addition to obesity & Prevalence & Genetic \\
\hline Prader-Willi & $\begin{array}{l}\text { Neonatal hypotonia, mental } \\
\text { retardation, hyperphagia, facial } \\
\text { dysmorphy, hypogonadotrophic } \\
\text { hypogonadism, short stature }\end{array}$ & $1 / 25,000$ births & $\begin{array}{l}\text { Lack of the paternal segment 15q11-q13 } \\
\text { (microdeletion, maternal disomy, } \\
\text { imprinting defect or reciprocal } \\
\text { translocation) }\end{array}$ \\
\hline Bardet-Biedl & $\begin{array}{l}\text { Mental retardation, retinal dystrophy } \\
\text { or pigmentary retinopathy, } \\
\text { dysmorphic extremities, } \\
\text { hypogonadism, kidney anomalies }\end{array}$ & $\begin{array}{l}1 / 125,000 \text { to } \\
1 / 175,000 \text { births }\end{array}$ & $\begin{array}{l}\text { BBS1 (11q13); BBS2 (16q12.2); BBS3 } \\
\text { (ARL6, 3q11); BBS4 (15q24.1); BBS5 } \\
\text { (2q31.1); BBS6 (MKKS, 20p12); BBS7 } \\
\text { (4q27); BBS8 (TTC8, 14q31); BBS9 (PTHB1, } \\
\text { 7p14); BBS10 (C12ORF58, 12q21.2); BBS } 11 \\
\text { (TRIM32, 9q33.1); BBS12 (FLJ35630, 4q27); } \\
\text { BBS13 (MKS1, 17q23); BBS14 (CEP290, } \\
\text { 12q21.3); BBS15 (WDPCP, 2p15); BBS16 } \\
\text { (SDCCAG8, 1q43); BBS17 (LZTFL1, 3p21); } \\
\text { BBS18 (BBIP1, 10q25); BBS19 (IFT27, } \\
\text { 22q12) }\end{array}$ \\
\hline Cohen & $\begin{array}{l}\text { Retinal dystrophy, prominent central } \\
\text { incisors, dysmorphic extremities, } \\
\text { microcephaly, cyclic neutropenia }\end{array}$ & $\begin{array}{l}\text { Diagnosed in fewer } \\
\text { than } 1,000 \text { patients } \\
\text { worldwide }\end{array}$ & $\begin{array}{l}\text { Autosomal recessive } \\
\text { COH1 gene (chr 8q22-q23) }\end{array}$ \\
\hline Alström & $\begin{array}{l}\text { Retinal dystrophy, neurosensory } \\
\text { deafness, diabetes, dilated } \\
\text { cardiomyopathy }\end{array}$ & $\begin{array}{l}\text { Diagnosed in about } \\
950 \text { patients } \\
\text { worldwide }\end{array}$ & $\begin{array}{l}\text { Autosomal recessive } \\
\text { ALMS1 gene (chr 2p13-p14). }\end{array}$ \\
\hline $\mathrm{X}$ fragile & $\begin{array}{l}\text { Mental retardation, hyperkinetic } \\
\text { behavior, macroorchidism, large ears, } \\
\text { prominent jaw }\end{array}$ & $1 / 2,500$ births & $\begin{array}{l}\text { X-linked } \\
\text { FMR1 gene (Xq27.3) }\end{array}$ \\
\hline $\begin{array}{l}\text { Borjeson- } \\
\text { Forssman- } \\
\text { Lehmann }\end{array}$ & $\begin{array}{l}\text { Mental retardation, hypotonia, } \\
\text { hypogonadism, facial dysmorphy with } \\
\text { large ears, epilepsy }\end{array}$ & $\begin{array}{l}\text { Approximately } 50 \\
\text { reported patients }\end{array}$ & $\begin{array}{l}\text { X-linked } \\
\text { PHF6 gene (Xq26-q27) }\end{array}$ \\
\hline $\begin{array}{l}\text { Albright hereditary } \\
\text { osteodystrophy }\end{array}$ & $\begin{array}{l}\text { Short stature, skeletal defects, facial } \\
\text { dysmorphy, endocrine anomalies }\end{array}$ & $1 / 1,000,000$ births & $\begin{array}{l}\text { Autosomal dominant } \\
\text { GNAS1 gene (20q13.2) }\end{array}$ \\
\hline $\begin{array}{l}16 \mathrm{p} 11.2 \text { deletion } \\
\text { syndrome }\end{array}$ & $\begin{array}{l}\text { Developmental delay, intellectual } \\
\text { disability, autism spectrum disorders, } \\
\text { impaired communication, socialization } \\
\text { skills }\end{array}$ & $\begin{array}{l}\text { Approximately } \\
3 / 10,000 \text { births }\end{array}$ & $\begin{array}{l}\text { Autosomal dominant } \\
\text { Microdeletion of } 16 \mathrm{p} 11.2\end{array}$ \\
\hline $\begin{array}{l}\text { Kinase suppressor } \\
\text { of Ras2 (KSR2) } \\
\text { variants }\end{array}$ & $\begin{array}{l}\text { Hyperphagia in childhood, low heart } \\
\text { rate, reduced basal metabolic rate, } \\
\text { severe insulin resistance }\end{array}$ & $\begin{array}{l}\text { Approximately } 65 \\
\text { reported patients }\end{array}$ & Rare $K S R 2$ variants (12q24.22-q24.23) \\
\hline TUB mutation & $\begin{array}{l}\text { Night blindness, decreased visual } \\
\text { acuity and electrophysiological } \\
\text { features of a rod-cone dystrophy }\end{array}$ & $\begin{array}{l}\text { Identified in } 3 \\
\text { affected sibs from } \\
\text { a consanguineous } \\
\text { Caucasian family }\end{array}$ & Homozygous TUB mutation (11p15.4) \\
\hline $\begin{array}{l}\text { ACP1, TMEM18, } \\
\text { MYT1L deletion }\end{array}$ & $\begin{array}{l}\text { Hyperphagia, intellectual deficiency, } \\
\text { severe behavioral difficulties }\end{array}$ & $\begin{array}{l}\text { Approximately } 13 \\
\text { reported patients }\end{array}$ & $\begin{array}{l}\text { Paternal deletion encompassing the } A C P 1 \text {, } \\
\text { TMEM18, MYT1L genes ( } 2 \mathrm{p} 25)\end{array}$ \\
\hline
\end{tabular}


Huvenne et al.: Rare Genetic Forms of Obesity: Clinical Approach and Current Treatments in 2016

everyday life despite a rapid increased consumption of calories in a test meal [28]. This observation might illustrate the determinant effect of the patient's (familial) environment and/or the possibility that voluntary caloric restriction may sometimes counteract the consequence of a lacking leptin signal. However, despite this particular case, severe early-onset obesity with major hyperphagia is recognized as the main clinical presentation of leptin or LEPR deficiency [27].

In addition to severe early-onset obesity, hypogonadotropic hypogonadism completes the phenotype of patients carrying mutations in the LEP or LEPR gene. No pubertal development was observed in some individuals with $L E P$ or $L E P R$ mutations, while in others there was evidence of spontaneous pubertal development suggesting a recovery of hormonal functions with time. For example, the follow-up of LEPR-deficient sisters revealed a normal spontaneous pregnancy [29]. Insufficient somatotropic secretion and thyrotropic insufficiency are also described in some patients with a $L E P R$ mutation $[5,26]$. LEPR mutations in severely obese subjects are not so rare with an estimated prevalence of $2-3 \%$ and need to be searched for in case of extreme obesity associated with endocrine abnormalities [23, 26, 30]. Recently, a congenital leptin deficiency due to biologically inactive leptin,was discovered in a young boy presenting with a clear clinical phenotype including extreme early-onset obesity and hyperphagia but high circulating leptin levels [31]. We recently reported on obese patients carrying homozygous LEPR mutations with slightly increased circulating leptin [26]. In summary, these observations demonstrate that circulating levels of leptin appearing normal in relation to BMI and fat mass do not rule out $L E P$ or $L E P R$ mutations.

Obese children with complete POMC deficiency have ACTH deficiency, mild central hypothyroidism [6] and sometimes alterations in the somatotropic and gonadotropic axes or inconstantly ginger hair [32]. The modifications in hair color, adrenal function, and body weight are consistent with the lack of $P O M C$-derived ligands for the melanocortin receptors MC1R, MC2R, and MC4R, respectively.

Patients carrying a rare mutation in the proprotein convertase subtilisin/kexin type 1 (PCSK1) gene have, in addition to severe obesity, postprandial hypoglycemic malaises, hypogonadotropic hypogonadism, central hypothyroidism and adrenal insufficiency [7]. The mutation in PCSK1 leads to a PC1 deficiency, an enzyme also involved in the maturation of insulin. Severe and rebel diarrhea, secondary to a lack in mature GLP-1 (glucagon-like peptide-1), is also described in case of $P C 1$ deficiency $[33,34]$ as well as persistent polydipsia and polyuria due to a central diabetes insipidus [35].

Other rare forms of obesity, due to mutations in several genes involved in the development of the hypothalamus and central nervous system, have been described in humans, allowing the identification of new pathways. Deletions of the SIM1 (single-minded homolog 1) gene have been identified in subjects with early-onset obesity associated with hyperphagia, food impulsivity and variable Prader-Willi-like features (neonatal hypotonia, dysmorphy, developmental delay, early-onset obesity, short stature, hypopituitarism] [36, 37]. SIM1 encodes a transcriptional factor involved in the development of the hypothalamic paraventricular nucleus, which plays a role in the melanocortin signaling pathway [38]. Sequencing of the coding region of SIM1 identified also rare heterozygous variants in patients who presented with severe obesity, hyperphagia, and variable neurobehavorial phenotype (impaired concentration, memory deficit, emotional lability or autistic spectrum behavior) [39]. Likewise, a de novo heterozygous mutation in the NTRK2 (neurotrophic tyrosine kinase receptor type 2) gene was described in an 8-year-old boy with severe early-onset obesity, mental retardation, developmental delay, and anomalies of higher neurological functions such as the impairment of early memory, learning, and nociception [40]. This gene encodes the brain-derived neurotropic factor (BDNF), and its associated tyrosine kinase receptor (TRKB) is involved in feeding regulation via a role downstream of MC4R signaling [41]. Other 
Huvenne et al.: Rare Genetic Forms of Obesity: Clinical Approach and Current Treatments in 2016

mutations in NTRK2 were found in patients with early-onset obesity and developmental delay, but their functional consequences and their implication in obesity are yet to be determined.

Obesity related to $M C 4 R$ mutations can be positioned between the exceptional forms of monogenic obesity and the polygenic common obesity and represents approximately 2-3\% of childhood and adult obesity [42]. It is mostly characterized by an autosomal dominant mode of transmission with incomplete age-related penetrance and a lack of additional obvious phenotypes. The severity of the phenotype is variable (moderate to severe obesity), depending on the role of the environment and other potentially modulating genetic factors [43]. Subjects carrying $M C 4 R$ mutations are usually heterozygous [44]. Homozygous or compound heterozygous carriers of $M C 4 R$ mutations are very rare, and their phenotype is thus more severe [45-47]. In addition to obesity, children carrying MC4R mutations have a marked hyperphagia that decreases with age [48]. Meanwhile, the association between binge eating disorder and MC4R mutations [49] has not been confirmed [43,44]. Hundreds of mutations have been identified with many functional alterations.

\section{Genetic Diagnosis}

If a rare genetic form of obesity is suspected, genetic diagnosis must be discussed and confided to specialists in reference centers (fig. 3).

In case of obesity associated with intellectual deficiency and/or behavioral difficulties, the genetic tests should include at least high-resolution karyotype, investigation of DNA methylation on chromosome 15 , fragile $\mathrm{X}$ search, and study by comparative genomic hybridization (CGH) array. Specific research for other monogenic anomalies (SIM1, MAGEL2, NTRK2) must be discussed depending on the clinical phenotype.

In the event of obesity associated with retinal dystrophy, a ciliopathy should be searched, in particular BBS.

In case of severe early-onset obesity associated with endocrine anomalies suggesting a monogenic obesity, direct sequencing of the candidate gene (LEP, LEPR, POMC, PCSK1) is necessary to confirm the diagnosis. It will detect homozygous or compound heterozygous mutations responsible for interruption of the leptin-melanocortin axis. Family members need to be tested by segregation analysis to evaluate the risk of recurrence.

In case of early-onset, severe, and isolated obesity, $M C 4 R$ mutations are detected by direct sequencing of the $M C 4 R$ gene (1 exon). The diagnosis can be performed in several centers in France and in Europe.

\section{Current Medical Treatment in Genetic Obesity}

It is important to diagnose genetic forms of obesity because specific management, provided by specialized and multidisciplinary teams, is needed as soon as possible (starting in early childhood).

No specific treatment is described for syndromic obesity except for its general management (diet and physical activity, psychomotricity, adapted physical activities, hormone substitution, etc.). In PWS, GH therapy with doses typically used for childhood growth (starting before 1 year of age) can improve growth, body composition, muscle thickness, physical strength and agility, motor performance, fat utilization, and lipid metabolism in children and adults with PWS [50,51]. Moreover, current active research on several molecules (beloranib, oxytocin, topiramate, ghrelin) is very promising for future treatment 
Huvenne et al.: Rare Genetic Forms of Obesity: Clinical Approach and Current Treatments in 2016

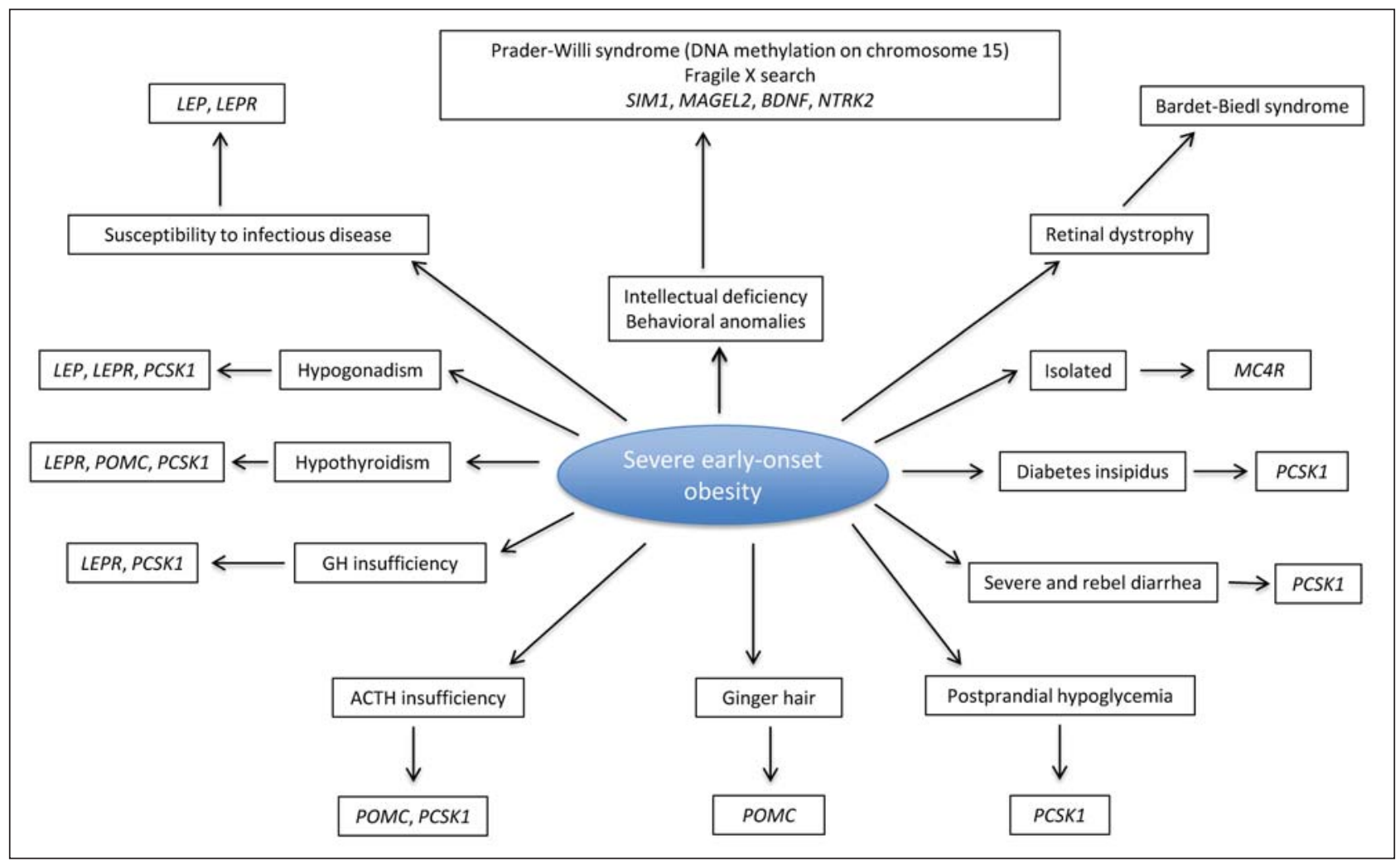

Fig. 3. Genetic diagnosis prioritization for severe early-onset obesity [4-7, 20, 22, 26, 36, 75]. BDNF = brainderived neurotropic factor; LEP = leptin; LEPR = leptin receptor; MAGEL2 = MAGE-like 2; MC4R = melanocortin 4 receptor; NTRK2 = neurotrophic tyrosine kinase receptor 2; PCSK1 = proprotein convertase subtilisin/kexin type $1 ;$ POMC = proopiomelanocortin; SIM1 = single-minded 1.

of PWS. Individuals with PWS have a significant reduction in the number of oxytocin-producing neurons in the hypothalamic paraventricular nucleus; and a number of the PWS features, such as hyperphagia, obesity and behavioral anomalies, may be due to consequent hypothalamic hyposecretion of oxytocin. Preliminary studies in mice and humans have investigated the capacity of exogenous oxytocin to improve physical, behavioral, and cognitive aspects of PWS, but further research is necessary to better understand the exact effects of oxytocin on syndrome-specific behaviors in patients with PWS [52, 53].

In case of monogenic obesity, subcutaneous injection of leptin in children and adults with LEP mutations resulted in weight loss, mainly of fat mass, with a major effect on reducing food intake [31, 54]. Leptin treatment also induces aspects of puberty, even in adults [27]. Because of a non-functional LEPR, leptin treatment is useless in LEPR-deficient subjects. Their medical management is challenging, just as that of POMC- and PC1-deficient patients. Drugs that could safely bypass normal leptin delivery systems are being developed but are currently not available for humans [55].

For MC4R-deficient obese patients, to date, no specific management has been suggested, except well-balanced diet and physical activity. Patients with $M C 4 R$ mutations were able to lose weight in a 1-year lifestyle intervention based on exercise, behavior, and nutrition therapy, but the maintenance of weight loss failed in contrast to patients without mutations [56]. Novel pharmacological MC4R agonists have been tested in vitro and can restore normal activity in mutated receptors. Preclinical trials are now being performed [57]. Thus, treatment 
Huvenne et al.: Rare Genetic Forms of Obesity: Clinical Approach and Current Treatments in 2016

Table 3. Surgical treatments in genetic forms of obesity

\begin{tabular}{|c|c|c|c|c|c|c|c|}
\hline $\begin{array}{l}\text { Type of } \\
\text { genetic } \\
\text { obesity }\end{array}$ & $\begin{array}{l}\text { Number } \\
\text { of cases }\end{array}$ & $\begin{array}{l}\text { Mean } \\
\text { age, } \\
\text { years }\end{array}$ & $\begin{array}{l}\text { Mean } \\
\text { follow-up, } \\
\text { years }\end{array}$ & $\begin{array}{l}\text { Bariatric } \\
\text { procedure }\end{array}$ & Results & $\begin{array}{l}\text { Postoperative } \\
\text { complications }\end{array}$ & References \\
\hline \multirow[t]{4}{*}{ PWS } & 24 & 10.7 & 5 & $\begin{array}{l}\text { sleeve } \\
\text { gastrectomy }\end{array}$ & $\begin{array}{l}\text { BMI loss of } 10.7 \% \text {; } \\
95 \% \text { of comorbidities } \\
\text { in remission or } \\
\text { improved }\end{array}$ & no complication & $\begin{array}{l}\text { Alqahtani et al, } \\
2015 \text { [60] }\end{array}$ \\
\hline & 3 & 18.7 & 2.7 & $\begin{array}{l}2 \text { sleeve } \\
\text { gastrectomy } \\
1 \text { gastric } \\
\text { bypass }\end{array}$ & $\begin{array}{l}\text { excessive weight loss } \\
\text { of } 63.2 \%\end{array}$ & $\begin{array}{l}\text { no major } \\
\text { complication }\end{array}$ & $\begin{array}{l}\text { Fong et al, } 2012 \\
{[61]}\end{array}$ \\
\hline & 3 & 15.6 & 2 & $\begin{array}{l}\text { mini-gastric } \\
\text { bypass }\end{array}$ & $\begin{array}{l}\text { excess weight loss of } \\
79 \% \text {; } \\
\text { resolution of } \\
\text { hypertension; } \\
\text { improved sleep apnea }\end{array}$ & $\begin{array}{l}\text { no surgical } \\
\text { complication }\end{array}$ & $\begin{array}{l}\text { Musella et al, } \\
2014 \text { [63] }\end{array}$ \\
\hline & 60 & 19.7 & 5 & $\begin{array}{l}\text { gastric } \\
\text { bypass } \\
\text { gastric } \\
\text { banding }\end{array}$ & $\begin{array}{l}\text { average weight loss of } \\
2.4 \%\end{array}$ & $\begin{array}{l}\text { variety of } \\
\text { postoperative } \\
\text { issues: death, } \\
\text { pulmonary embolus, } \\
\text { wound infection, } \\
\text { gastric perforation }\end{array}$ & $\begin{array}{l}\text { Scheimann et al, } \\
2008 \text { [64] }\end{array}$ \\
\hline $\begin{array}{l}\text { Syndromic } \\
\text { obesity }\end{array}$ & $\begin{array}{l}16 \text { PWS } \\
6 \text { BBS } \\
1 \text { Alström } \\
\text { syndrome }\end{array}$ & 11.7 & 4 & $\begin{array}{l}\text { sleeve } \\
\text { gastrectomy }\end{array}$ & $\begin{array}{l}\text { excess BMI loss of } \\
60.2 \% \text {; } \\
\text { resolution of more } \\
\text { than } 90 \% \text { of } \\
\text { comorbidities }\end{array}$ & $\begin{array}{l}\text { no significant } \\
\text { complication }\end{array}$ & $\begin{array}{l}\text { Alqahtani et al, } \\
2014 \text { [62] }\end{array}$ \\
\hline \multirow[t]{3}{*}{ BBS } & 1 & 16 & 3.5 & $\begin{array}{l}\text { gastric } \\
\text { bypass }\end{array}$ & $\begin{array}{l}\text { BMI loss of 33.3\%; } \\
\text { significant } \\
\text { improvement in } \\
\text { hypertension and } \\
\text { mobility }\end{array}$ & no complication & $\begin{array}{l}\text { Daskalakis et al, } \\
2010 \text { [65] }\end{array}$ \\
\hline & 1 & 33 & 1 & $\begin{array}{l}\text { sleeve } \\
\text { gastrectomy }\end{array}$ & weight loss of $23.9 \%$ & $\begin{array}{l}\text { no significant } \\
\text { complication }\end{array}$ & $\begin{array}{l}\text { Mujahid et al, } \\
2014 \text { [66] }\end{array}$ \\
\hline & 1 & 35 & 2.2 & $\begin{array}{l}\text { gastric } \\
\text { banding }\end{array}$ & $\begin{array}{l}\text { weight loss of } 9 \% \text {; } \\
\text { no effect on type } 2 \\
\text { diabetes }\end{array}$ & no complication & $\begin{array}{l}\text { Mujahid et al, } \\
2014 \text { [66] }\end{array}$ \\
\hline \multirow[t]{4}{*}{$\begin{array}{l}L E P R \\
\text { mutations }\end{array}$} & 1 & 16 & 8 & $\begin{array}{l}\text { vertical } \\
\text { gastroplasty }\end{array}$ & weight loss of $20 \%$ & no complication & $\begin{array}{l}\text { Le Beyec et al, } \\
2013 \text { [67] }\end{array}$ \\
\hline & 1 & 18 & 0.8 & $\begin{array}{l}\text { vertical } \\
\text { gastroplasty }\end{array}$ & weight loss of $44 \%$ & no complication & $\begin{array}{l}\text { Huvenne et al, } \\
2015 \text { [26] }\end{array}$ \\
\hline & 1 & 26 & 1.5 & $\begin{array}{l}\text { gastric } \\
\text { bypass }\end{array}$ & weight loss of $10 \%$ & no complication & $\begin{array}{l}\text { Le Beyec et al, } \\
2013 \text { [67] }\end{array}$ \\
\hline & 1 & 36 & 5 & $\begin{array}{l}\text { gastric } \\
\text { bypass }\end{array}$ & weight loss of $7 \%$ & no complication & $\begin{array}{l}\text { Huvenne et al, } \\
2015 \text { [26] }\end{array}$ \\
\hline
\end{tabular}


Huvenne et al.: Rare Genetic Forms of Obesity: Clinical Approach and Current

Treatments in 2016

Table 3 (continued)

\begin{tabular}{|c|c|c|c|c|c|c|c|}
\hline $\begin{array}{l}\text { Type of } \\
\text { genetic } \\
\text { obesity }\end{array}$ & $\begin{array}{l}\text { Number } \\
\text { of cases }\end{array}$ & $\begin{array}{l}\text { Mean } \\
\text { age, } \\
\text { years }\end{array}$ & $\begin{array}{l}\text { Mean } \\
\text { follow-up, } \\
\text { years }\end{array}$ & $\begin{array}{l}\text { Bariatric } \\
\text { procedure }\end{array}$ & Results & $\begin{array}{l}\text { Postoperative } \\
\text { complications }\end{array}$ & References \\
\hline \multirow{4}{*}{$\begin{array}{l}\text { Heterozygous } \\
M C 4 R \\
\text { mutations }\end{array}$} & 4 & 45.5 & 1 & gastric bypass & $\begin{array}{l}\text { excess weight loss of } \\
60 \%\end{array}$ & $\begin{array}{l}1 \text { aspiration } \\
\text { pneumonia }\end{array}$ & $\begin{array}{l}\text { Aslan et al, } 2011 \\
{[68]}\end{array}$ \\
\hline & 9 & 36.2 & 1 & $\begin{array}{l}3 \text { gastric } \\
\text { banding } \\
6 \text { gastric } \\
\text { bypass }\end{array}$ & weight loss of $25.9 \%$ & $\begin{array}{l}\text { no significant } \\
\text { complication }\end{array}$ & $\begin{array}{l}\text { Valette et al, } \\
2012 \text { [69] }\end{array}$ \\
\hline & 1 & 22 & 4.8 & gastric bypass & $\begin{array}{l}\text { excess weight loss of } \\
76 \%\end{array}$ & no complication & $\begin{array}{l}\text { Elkhenini et al, } \\
2014 \text { [70] }\end{array}$ \\
\hline & 4 & 18.6 & 1 & $\begin{array}{l}3 \text { gastric } \\
\text { banding } \\
1 \text { sleeve } \\
\text { gastrectomy }\end{array}$ & $\begin{array}{l}\text { excess weight loss of } \\
48.6 \%\end{array}$ & no complication & $\begin{array}{l}\text { Censani et al, } \\
2014[71]\end{array}$ \\
\hline $\begin{array}{l}\text { Homozygous } \\
M C 4 R \\
\text { mutations }\end{array}$ & 1 & 17 & 1 & $\begin{array}{l}\text { gastric } \\
\text { banding }\end{array}$ & weight gain of $7 \%$ & no complication & $\begin{array}{l}\text { Aslan et al, } 2011 \\
\text { [72] }\end{array}$ \\
\hline
\end{tabular}

with a highly-selective novel MC4R agonist in obese animal models resulted in decreased food intake, increased total energy expenditure, weight loss, and weight-independent improvement of insulin sensitivity after 8 weeks of treatment. No side effects, particularly those affecting blood pressure or heart rate, were observed in these studies [58].

\section{Surgical Treatments in Genetic Obesity}

The question of the potential efficiency of bariatric surgery arises in patients with genetic obesity. Indeed, today, bariatric surgery (laparoscopic gastric bypass, gastric banding, or sleeve gastrectomy) is the only long-term efficient treatment for severe obesity [59]. Currently, data on such treatments in patients with genetic obesity are limited and still controversial (table 3).

In PWS, the indication of bariatric surgery is highly discussed due to early-onset morbid obesity. In 24 recently described patient cases (mean age 10.7 years), bariatric surgery was reported to be beneficial. After laparoscopic sleeve gastrectomy, BMI loss was $14.7 \%(n=22$ patients) and $10.7 \%$ ( $n=7$ patients) on the first and fifth annual visit, respectively. 95\% of comorbidities (obstructive sleep apnea, dyslipidemia, hypertension, and diabetes mellitus) were in remission or improved. No postoperative complications occurred [60]. In another study, two 15- or 23-year-old patients and one18-year-old patient underwent laparoscopic sleeve gastrectomy and laparoscopic gastric bypass surgery, respectively. After a median follow-up of 33 months, mean weight loss and percentage of excessive weight loss at 2 years were $32.5 \mathrm{~kg}$ and $63.2 \%$, respectively. No major complication was observed [61]. In another study, 23 syndromic patients with an average age of 11.7 years (16 with PWS, 6 with BBS, and 1 with Alström syndrome) underwent laparoscopic sleeve gastrectomy. These patients who completed 4 years of follow-up experienced an average excess BMI loss of $60.2 \%$, with resolution of more than $90 \%$ of comorbidities and no significant complications [62]. Three additional young male PWS patients (mean age 15.6 years) were treated by mini-gastric bypass 
Huvenne et al.: Rare Genetic Forms of Obesity: Clinical Approach and Current Treatments in 2016

and showed excessive weight loss of $79 \%$ within 2 years, resolution of hypertension, and improved sleep apnea. No surgical complication was reported [63]. These observations are in contrast to a retrospective review including 60 cases of PWS patients who underwent bariatric surgery (mean age at the time of bariatric procedure $19.7 \pm 6.4$ years). Various bariatric procedures have been used, with poor results in PWS patients in comparison to normal obese individuals. Five years after gastric bypass surgery and after gastric banding, the reported average weight loss was only $2.4 \%$ and $3.5 \%$ compared to the preoperative weight, respectively. In addition to poor results on weight, a variety of postoperative issues was reported, including death, pulmonary embolus, postoperative wound infection, and gastric perforation [64]. In conclusion, the indication of this therapeutic option in PWS needs to be discussed extensively in reference centers. Surgery should not replace multidisciplinary medical management, i.e. early diagnosis and multidisciplinary care with GH treatment, reduced-energy diets with restricted access to food, and regular physical activity, which has proven its effectiveness and safety in patients with PWS.

In BBS, the indication of bariatric surgery is also discussed. A morbidly obese 16-year-old patient with BBS underwent laparoscopic Roux-en-Y gastric bypass surgery. The postoperative period was uneventful. The BMI decreased from 52.28 to $34.85 \mathrm{~kg} / \mathrm{m}^{2}$ within 42 months after surgery, with significant improvement in hypertension and mobility [65]. In another study, a 33-year-old morbidly obese woman with BBS underwent a sleeve gastrectomy without significant postoperative complications. The intervention resulted in a significant weight loss of $23.9 \%$ within 12 months [66]. In contrast, gastric banding, performed in a 35 -year-old morbidly obese man with BBS, resulted in only a small weight loss of $9 \%$ without effect on type 2 diabetes [66]. Apparently, longer follow-up is required to evaluate long-term safety and efficacy of bariatric surgery in patients with BBS.

In two LEPR-deficient patients, vertical gastroplasty appears to be beneficial inducing a weight loss of $40 \mathrm{~kg}(-20 \%$ of the initial weight) in a 16-year-old patient within 8 years of regular follow-up [67] and a significant initial weight loss (-44\% of weight in 9 months) in an 18-year-old patient [26]. In contrast, relative failure was observed in another 26-year-old LEPR-deficient morbidly obese woman with rapid weight regain 1 year after bypass surgery. However, this patient with low socioeconomic status was noncompliant to the recommendations provided for this type of surgery and had a very irregular medical follow-up [67]. In another 36-year-old LEPR-deficient patient, gastric bypass did not induce significant weight loss in the long term either ( $-7 \% 5$ years after surgery) [26]. These reports probably illustrated the important role of familial environment regarding the efficacy of bariatric surgery in monogenic forms of obesity.

In patients with heterozygous $M C 4 R$ mutations (mean age 32.2 years), effects of weight loss surgery are identical to those in patients without MC4R mutations, suggesting that heterozygous MC4R mutation status should not influence the decision [68-71]. In contrast, laparoscopic adjustable gastric banding in a 17-year-old teenager with homozygous $M C 4 R$ mutation resulted in the absence of a long-term weight loss (12 months postoperatively), suggesting that the full interruption of the melanocortin pathway may not be counteracted by bariatric surgery [72]. More studies with a long-term follow-up on the effect of bariatric surgery in $M C 4 R$-mutated patients are required.

Thus, due to the limited number of cases, the long-term efficacy and safety of bariatric surgery in genetic forms of obesity need further evaluation. A multidisciplinary team approach should always be adopted in order to discuss a possible surgery procedure in this context. It should be kept in mind that severe eating disorders are usually an argument against bariatric surgery. The position of the French Reference Center of Prader-Willi Syndrome is cautious and does not recommend the use of surgery in case of syndromic obesity with food impulsivity. 
Huvenne et al.: Rare Genetic Forms of Obesity: Clinical Approach and Current Treatments in 2016

\section{Perspectives}

Deep brain stimulation (DBS) targeting the hypothalamus and the nucleus accumbens, two brain regions for which dysfunction appears to be directly associated with food stimuli, seems to be promising for treatment-refractory obesity. In particular, patients with PWS may represent a target group for treatment with DBS, given the overlap between the obesity secondary to hyperphagia and the dysregulation reward circuitry observed in this disorder (abnormal basal activity in the lateral hypothalamus and the nucleus accumbens). Clinical trials will have to evaluate the efficacy of DBS for genetic forms of obesity [73].

Using pharmacological chaperones for MC4R represents a possibility for the development of a targeted treatment of severe early-onset obesity caused by MC4R mutations. A study demonstrated that a novel human MC4R antagonist, Ipsen 17, serving as a pharmacological chaperone of human MC4R, increased the cell surface expression of MC4R mutants and their signaling capacity upon $\alpha$-MSH stimulation [74]. Thus, using pharmacological chaperones against $M C 4 R$ mutants provides an exciting disease-modifying opportunity for severe early-onset morbid obesity.

\section{Conclusion}

Genetic forms of obesity are important to diagnose because they need a specific management based on multidisciplinary teams which is to be set up as soon as possible. New treatments have recently emerged, particularly for PWS and mutations of the leptin/melanocortin pathway, which could change the prognosis for these rare severe forms of obesity. However, to date, causal therapy is not available for most forms of obesity.

Moreover, progress in understanding of genetic obesity mechanisms, particularly by applying whole-exome sequencing, may probably help physicians to identify new molecular anomalies in patients with severe early-onset obesity in the near future in order to better understand the pathophysiology of more common forms of obesity and to improve their care management.

\section{Disclosure Statement}

The authors have not declared any conflicts of interest.

\section{References}

1 de Onis M, Blössner M, Borghi E: Global prevalence and trends of overweight and obesity among preschool children. Am J Clin Nutr 2010;92:1257-1264.

2 Dubern B, Clément K: Aspects génétiques de l’obésité. Presse Med 2007;36:1568-1605.

3 Zhang Y, Proenca R, Maffei M, Barone M, Leopold L, Friedman JM: Positional cloning of the mouse obese gene and its human homologue. Nature 1994;372:425-432.

4 Montague CT, Farooqi IS, Whitehead JP, Soos MA, Rau H, Wareham NJ, Sewter CP, Digby JE, Mohammed SN, Hurst JA, Cheetham CH, Earley AR, Barnett AH, Prins JB, O’Rahilly S: Congenital leptin deficiency is associated with severe early-onset obesity in humans. Nature 1997;387:903-908.

5 Clément K, Vaisse C, Lahlou N, Cabrol S, Pelloux V, Cassuto D, Gourmelen M, Dina C, Chambaz J, Lacorte JM, Basdevant A, Bougnères P, Lebouc Y, Froguel P, Guy-Grand B: A mutation in the human leptin receptor gene causes obesity and pituitary dysfunction. Nature 1998;392:398-401.

6 Krude H, Biebermann H, Schnabel D, Tansek MZ, Theunissen P, Mullis PE, Grüters A: Obesity due to proopiomelanocortin deficiency: three new cases and treatment trials with thyroid hormone and ACTH4-10. J Clin Endocrinol Metab 2003;88:4633-4640. 
Huvenne et al.: Rare Genetic Forms of Obesity: Clinical Approach and Current

Treatments in 2016

7 Jackson RS, Creemers JW, Ohagi S, Raffin-Sanson ML, Sanders L, Montague CT, Hutton JC, O’Rahilly S: Obesity and impaired prohormone processing associated with mutations in the human prohormone convertase 1 gene. Nat Genet 1997; 16:303-306.

8 Yazdi FT, Clee SM, Meyre D: Obesity genetics in mouse and human: back and forth, and back again. Peer J 2015; 3:e856.

9 Frayling TM, Timpson NJ, Weedon MN, Zeggini E, Freathy RM, Lindgren CM, Perry JR, Elliott KS, Lango H, Rayner NW, Shields B, Harries LW, Barrett JC, Ellard S, Groves CJ, Knight B, Patch AM, Ness AR, Ebrahim S, Lawlor DA, Ring SM, Ben-Sholmo Y, Jarvelin MR, Sovio U, Bennett AJ, Melzer D, Ferrucci L, Loos RJ, Barroso I, Wareham NJ, Karpe F, Owen KR, Cardon LR, Walker M, Hitman GA, Palmer CN, Doney AS, Morris AD, Smith GD, Hattersley AT, McCarthy MI: A common variant in the FTO gene is associated with body mass index and predisposes to childhood and adult obesity. Science 2007;316:889-894.

10 Saeed S, Bonnefond A, Manzoor J, Philippe J, Durand E, Arshad M, Sand O, Butt TA, Falchi M, Arslan M, Froguel P: Novel LEPR mutations in obese Pakistani children identified by PCR-based enrichment and next generation sequencing. Obesity (Silver Spring) 2014;22:1112-1117.

11 Xing DJ, Zhang HX, Huang N, Wu KC, Huang XF, Huang F, Tong Y, Pang CP, Qu J, Jin ZB: Comprehensive molecular diagnosis of Bardet-Biedl syndrome by high-throughput targeted exome sequencing. Plos One 2014;9:e90599.

12 Doco-Fenzi M, Leroy C, Schneider A, Petit F, Delrue MA, Andrieux J, Perrin-Sabourin L, Landais E, Aboura A Puechberty J, Girard M, Tournaire M, Sanchez E, Rooryck C, Ameil A, Goossens M, Jonveaux P, Lefort G, Taine L, Cailley D, Gaillard D, Leheup B, Sarda P, Geneviève D: Early-onset obesity and paternal 2pter deletion encompassing the ACP1, TMEM18, and MYT1L genes. Eur J Hum Genet 2014;22:471-479.

13 Pearce LR, Atanassova N, Banton MC, Bottomley B, van der Klaauw AA, Revelli JP, Hendricks A, Keogh JM, Henning E, Doree D, Jeter-Jones S, Garg S, Bochukova EG, Bounds R, Ashford S, Gayton E, Hindmarsh PC, Shield JP, Crowne E, Barford D, Wareham NJ, UK10K consortium, O’Rahilly S, Murphy MP, Powell DR, Barroso I, Farooqi IS: KSR2 mutations are associated with obesity, insulin resistance, and impaired cellular fuel oxidation. Cell 2013;155:765-777.

14 Borman AD, Pearce LR, Mackay DS, Nagel-Wolfrum K, Davidson AE, Henderson R, Garg S, Waseem NH, Webster AR, Plagnol V, Wolfrum U, Farooqi IS, Moore AT: A homozygous mutation in the TUB gene associated with retinal dystrophy and obesity. Hum Mutat 2014;35:289-293.

15 Alsters SI, Goldstone AP, Buxton JL, Zekavati A, Sosinsky A, Yiorkas AM, Holder S, Klaber RE, Bridges N, van Haelst MM, le Roux CW, Walley AJ, Walters RG, Mueller M, Blakemore AI: Truncating homozygous mutation of carboxypeptidase $\mathrm{E}(\mathrm{CPE})$ in a morbidly obese female with type 2 diabetes mellitus, intellectual disability and hypogonadotrophic hypogonadism. Plos One 2015;10:e0131417.

16 Thaker VV, Esteves KM, Towne MC, Brownstein CA, James PM, Crowley L, Hirschhorn JN, Elsea SH, Beggs AH, Picker J, Agrawal PB: Whole exome sequencing identifies RAI1 mutation in a morbidly obese child diagnosed with ROHHAD syndrome. J Clin Endocrinol Metab 2015;100:1723-1730.

17 Vals MA, Oiglane-Shlik E, Noukas M, Shor R, Peet A, Kals M, Kivistik PA, Metspalu A, Öunap K: Coffin-Siris syndrome with obesity, macrocephaly, hepatomegaly and hyperinsulinism caused by a mutation in the ARID1B gene. Eur J Hum Genet 2014;22:1327-1329.

18 Miller JL, Lynn CH, Driscoll DC, Goldstone AP, Gold JA, Kimonis V, Dykens E, Butler MG, Shuster JJ, Driscoll DJ: Nutritional phases in Prader-Willi syndrome. Am J Med Genet A 2011;155:1040-1049.

19 Lloret-Linares C, Faucher P, Coupaye M, Alili R, Green A, Basdevant A, Clément K, Poitou C: Comparison of body composition, basal metabolic rate and metabolic outcomes of adults with Prader Willi syndrome or lesional hypothalamic disease, with primary obesity. Int J Obes 2013;37:1198-1203.

20 Goldstone AP, Beales PL: Genetic obesity syndromes. Front Horm Res 2008;36:37-60.

21 Horsthemke B, Buiting K: Imprinting defects on human chromosome 15. Cytogenet Genome Res 2006;113: 292-299.

22 Schaaf CP, Gonzalez-Garay ML, Xia F, Potocki L, Gripp KW, Zhang B, Peters BA, McElwain MA, Drmanac R, Beaudet AL, Caskey CT, Yang Y: Truncating mutations of MAGEL2 cause Prader-Willi phenotypes and autism. Nat Genet 2013;45:1405-1409.

23 M'hamdi O, Ouertani I, Chaabouni-Bouhamed H: Update on the genetics of Bardet-Biedl syndrome. Mol Syndromol 2014;5:51-56.

24 Zaghloul NA, Katsanis N: Mechanistics insights into Bardet-Biedl syndrome, a model ciliopathy. J Clin Invest 2009;119:428-437.

25 Chennen K, Scerbo MJ, Dollfus H, Poch O, Marion V: Bardet-Biedl syndrome: cilia and obesity - from genes to integrative approaches (in French). Med Sci (Paris) 2014;30:1034-1039.

26 Huvenne H, Le Beyec J, Pépin D, Alili R, Pigeon Kherchiche P, Jeannic E, Frelut ML, Lacorte JM, Nicolino M, Viard A, Laville M, Ledoux S, Tounian P, Poitou C, Dubern B, Clément K: Seven novel deleterious LEPR mutations found in early-onset obesity: a $\triangle$ exon6-8 shared by subjects from Reunion Island, France suggests a founder effect. J Clin Endocrinol Metab 2015;100:757-766.

27 Licinio J, Caglayan S, Ozata M, Yildiz BO, de Miranda PB, O’Kirwan F, Whitby R, Liang L, Cohen P, Bhasin S, Krauss RM, Veldhuis JD, Wagner AJ, DePaoli AM, McCann SM, Wong ML: Phenotypic effects of leptin replacement on morbid obesity, diabetes mellitus, hypogonadism, and behavior in leptin-deficient adults. Proc Natl Acad Sci U S A 2004;101:4531-4536. 
Huvenne et al.: Rare Genetic Forms of Obesity: Clinical Approach and Current

Treatments in 2016

28 Fischer-Posovszky P, von Schnurbein J, Moepps B, Lahr G, Strauss G, Barth TF, Kassubek J, Mühleder H, Möller P, Debatin KM, Gierschik P, Wabitsch M: A new missense mutation in the leptin gene causes mild obesity and hypogonadism without affecting T cell responsiveness. J Clin Endocrinol Metab 2010;95:2836-2840.

29 Nizard J, Dommergues M, Clément K: Pregnancy in a woman with a leptin-receptor mutation. N Engl J Med 2012;366:1064-1065.

30 Farooqi IS, Wangensteen T, Collins S, Kimber W, Matarese G, Keogh JM, Lank E, Bottomley B, Lopez-Fernandez J, Ferraz-Amaro I, Dattani MT, Ercan 0, Myhre AG, Retterstol L, Stanhope R, Edge JA, McKenzie S, Lessan N, Ghodsi M, De Rosa V, Perna F, Fontana S, Barroso I, Undlien DE, O’Rahilly S: Clinical and molecular genetic spectrum of congenital deficiency of the leptin receptor. N Engl J Med 2007;356:237-247.

31 Wabitsch M, Funcke JB, Lennerz B, Kuhnle-Krahl U, Lahr G, Debatin KM, Vatter P, Gierschik P, Moepps B, Fischer-Posovszky P: Biologically inactive leptin and early-onset extreme obesity. N Engl J Med 2015;372: 48-54.

32 Clément K, Dubern B, Mencarelli M, Czernichow P, Ito S, Wakamatsu K, Barsh GS, Vaisse C, Leger J: Unexpected endocrine features and normal pigmentation in a young adult patient carrying a novel homozygous mutation in the POMC gene. J Clin Endocrinol Metab 2008;93:4955-4962.

33 Jackson RS, Creemers JW, Farooqi IS, Raffin-Sanson ML, Varro A, Dockray GJ, Holst JJ, Brubaker PL, Corvol P, Polonsky KS, Ostrega D, Becker KL, Bertagna X, Hutton JC, White A, Dattani MT, Hussain K, Middleton SJ, Nicole TM, Milla PJ, Lindley KJ, O’Rahilly S: Small-intestinal dysfunction accompanies the complex endocrinopathy of human proprotein convertase 1 deficiency. J Clin Invest 2003;112:1550-1560.

34 Martin MG, Lindberg I, Solorzano-Vargas RS, Wang J, Avitzur Y, Bandsma R, Sokollik C, Lawrence S, Pickett LA, Chen Z, Egritas O, Dalgic B, Albornoz V, de Ridder L, Hulst J, Gok F, Aydogan A, Al-Hussaini A, Gok DE, Yourshaw M, Wu SV, Cortina G, Stanford S, Georgia S: Congenital proprotein convertase 1/3 deficiency causes malabsorptive diarrhea and other endocrinopathies in a pediatric cohort. Gastroenterology 2013;145:138-148.

35 Frank GR, Fox J, Candela N, Jovanovic Z, Bochukova E, Levine J, Papenhausen PR, O’Rahilly S, Farooqi IS: Severe obesity and diabetes insipidus in a patient with PCSK1 deficiency. Mol Genet Metab 2013;110:191-194.

36 Holder JLJr, Butte NF, Zinn AR: Profound obesity associated with a balanced translocation that disrupts the SIM1 gene. Hum Mol Genet 2000;9:101-108.

37 Izumi K, Housam R, Kapadia C, Stallings VA, Medne L, Shaikh TH, Kublaoui BM, Zackai EH, Grimberg A: Endocrine phenotype of 6q16.1-q21 deletion involving SIM1 and Prader-Willi syndrome-like features. Am J Med Genet 2013;161A:3137-3143.

38 Michaud JL, Boucher F, Melnyk A, Gauthier F, Goshu E, Lévy E, Mitchell GA, Himms-Hagen J, Fan CM: Sim1 haploinsufficiency causes hyperphagia, obesity and reduction of the paraventricular nucleus of the hypothalamus. Hum Mol Genet 2001;10:1465-1473.

39 Ramachandrappa S, Raimondo A, Cali AM, Keogh JM, Henning E, Saeed S, Thompson A, Garg S, Bochukova EG, Brage S, Trowse V, Wheeler E, Sullivan AE, Dattani M, Clayton PE, Datta V, Bruning JB, Wareham NJ, O’Rahilly S, Peet DJ, Barroso I, Whitelaw ML, Farooqi IS: Rare variants in single-minded 1 (SIM1) are associated with severe obesity. J Clin Invest 2013;123:3042-3050.

40 Yeo GS, Connie Hung CC, Rochford J, Keogh J, Gray J, Sivaramakrishnan S, O’Rahilly S, Farooqi IS: A de novo mutation affecting human TrkB associated with severe obesity and developmental delay. Nat Neurosci 2004; 7:1187-1189.

41 Xu B, Goulding EH, Zang K, Cepoi D, Cone RD, Jones KR, Tecott LH, Reichardt LF: Brain-derived neurotrophic factor regulates energy balance downstream of melanocortin-4 receptor. Nat Neurosci 2003;6:736-742.

42 Hinney A, Volckmar AL, Knoll N: Melanocortin-4 receptor in energy homeostasis and obesity pathogenesis. Prog Mol Biol Transl Sci 2013;114:147-191.

43 Lubrano-Berthelier C, Dubern B, Lacorte JM, Picard F, Shapiro A, Zhang S, Bertrais S, Hercberg S, Basdevant A, Clement K, Vaisse C: Melanocortin 4 receptor mutations in a large cohort of severely obese adults: prevalence, functional classification, genotype-phenotype relationship, and lack of association with binge eating. J Clin Endocrinol Metab 2006;91:1811-1818.

44 Valette M, Poitou C, Kesse-Guyot E, Bellisle F, Carette C, Le Beyec J, Hercberg S, Clément K, Czernichow S: Association between melanocortin-4 receptor mutations and eating behaviors in obese patients: a case-control study. Int J Obes 2014;38:883-885.

45 Farooqi IS, Keogh JM, Yeo GS, Lank EJ, Cheetham T, O’Rahilly S: Clinical spectrum of obesity and mutations in the melanocortin 4 receptor gene. N Engl J Med 2003;348:1085-1095.

46 Lubrano-Berthelier C, Le Stunff C, Bougnères P, Vaisse C: A homozygous null mutation delineates the role of the melanocortin-4 receptor in humans. J Clin Endocrinol Metab 2004;89:2028-2032.

47 Dubern B, Bisbis S, Talbaoui H, Le Beyec J, Tounian P, Lacorte JM, Clément K: Homozygous null mutation of the melanocortin-4 receptor and severe early-onset obesity. J Pediatr 2007;150:613-617.

48 MacKenzie RG: Obesity-associated mutations in the human melanocortin-4 receptor gene. Peptides 2006;27: 395-403.

49 Branson R, Potoczna N, Kral JG, Lentes KU, Hoehe MR, Horber FF: Binge eating as a major phenotype of melanocortin 4 receptor gene mutations. N Engl J Med 2003;348:1096-1103.

50 Carrel AL, Myers SE, Whitman BY, Eickhoff J, Allen DB: Long-term growth hormone therapy changes the natural history of body composition and motor function in children with Prader-Willi syndrome. J Clin Endocrinol Metab 2010;95:1131-1136. 
Huvenne et al.: Rare Genetic Forms of Obesity: Clinical Approach and Current

Treatments in 2016

51 Sanchez-Ortiga R, Klibanski A, Tritos NA: Effects of recombinant human growth hormone therapy in adults with Prader-Willi syndrome: a meta-analysis. Clin Endocrinol 2012;77:86-93.

52 Einfeld SL, Smith E, McGregor IS, Steinbeck K, Taffe J, Rice LJ, Horstead SK, Rogers N, Hodge MA, Guastella AJ: A double-blind randomized controlled trial of oxytocin nasal spray in Prader-Willi syndrome. Am J Med Genet A 2014;164A: 2232-2239.

53 Meziane H, Schaller F, Bauer S, Villard C, Matarazzo V, Riet F, Guillon G, Lafitte D, Desarmenien MG, Tauber M, Muscatelli F: An early postnatal oxytocin treatment prevents social and learning deficits in adult mice deficient for Magel2, a gene involved in Prader-Willi syndrome and autism. Biol Psychiatry 2015;78:85-94.

54 Farooqi IS, Matarese G, Lord GM, Keogh JM, Lawrence E, Agwu C, Sanna V, Jebb SA, Perna F, Fontana S, Lechler RI, DePaoli AM, O’Rahilly S: Beneficial effects of leptin on obesity, T cell hyporesponsiveness, and neuroendocrine/metabolic dysfunction of human congenital leptin deficiency. J Clin Invest 2002;110:1093-1103.

55 Boughton CK, Murphy KG: Can neuropeptides treat obesity? A review of neuropeptides and their potential role in the treatment of obesity. Br J Pharmacol 2013;170:1333-1348.

56 Reinehr T, Hebebrand J, Friedel S, Toschke AM, Brumm H, Biebermann H, Hinney A: Lifestyle intervention in obese children with variations in the melanocortin 4 receptor gene. Obesity (Silver Spring) 2009;17:382-389.

57 Fani L, Bak S, Delhanty P, van Rossum EFC, van den Akker ELT: The melanocortin-4 receptor as target for obesity treatment: a systematic review of emerging pharmacological therapeutic options. Int J Obes 2014;38: 163-169.

58 Kievit P, Halem H, Marks DL, Dong JZ, Glavas MM, Sinnayah P, Pranger L, Cowley MA, Grove KL, Culler MD: Chronic treatment with a melanocortin-4 receptor agonist causes weight loss, reduces insulin resistance, and improves cardiovascular function in diet-induced obese rhesus macaques. Diabetes 2013;62:490-497.

59 Sjöström L: Review of the key results from the Swedish Obes Subjects (SOS) trial - a prospective controlled intervention study of bariatric surgery. J Intern Med 2013;273:219-234.

60 Alqahtani AR, Elahmedi MO, Al Qahtani AR, Lee J, Butler MG: Laparoscopic sleeve gastrectomy in children and adolescents with Prader-Willi syndrome: a matched-control study. Surg Obes Relat Dis 2015;12:100-110.

61 Fong AKW, Wong SKH, Lam CCH, Ng EKW: Ghrelin level and weight loss after laparoscopic sleeve gastrectomy and gastric mini-bypass for Prader-Willi syndrome in Chinese. Obes Surg 2012;22:1742-1745.

62 Alqahtani AR, Elahmedi M, Alqahtani YA: Bariatric surgery in monogenic and syndromic forms of obesity. Semin Pediatr Surg 2014;23:37-42.

63 Musella M, Milone M, Leongito M, Maietta P, Bianco P, Pisapia A: The mini-gastric bypass in the management of morbid obesity in Prader-Willi syndrome: a viable option? J Invest Surg 2014;27:102-105.

64 Scheimann AO, Butler MG, Gourash L, Cuffari C, Kish W: Critical analysis of bariatric procedures in Prader-Willi syndrome. J Pediatr Gastroenterol Nutr 2008;46:80-83.

65 Daskalakis M, Tili H, Kiess W, Weiner RA: Roux-en-Y gastric bypass in an adolescent patient with Bardet-Biedl syndrome, a monogenic obesity disorder. Obes Surg 2010;20:121-125.

66 Mujahid S, Huda MS, Beales P, Carroll PV, McGowan BM: Adjustable gastric banding and sleeve gastrectomy in Bardet-Biedl syndrome. Obes Surg 2014;24:1746-1748.

67 Le Beyec J, Cugnet-Anceau C, Pépin D, Alili R, Cotillard A, Lacorte JM, Basdevant A, Laville M, Clément K: Homozygous leptin receptor mutation due to uniparental disomy of chromosome 1: response to bariatric surgery. J Clin Endocrinol Metab 2013;98:397-402.

68 Aslan IR, Campos GM, Calton MA, Evans DS, Merriman RB, Vaisse C: Weight loss after Roux-en-Y gastric bypass in obese patients heterozygous for MC4R mutations. Obes Surg 2011;21:930-934.

69 Valette M, Poitou C, Le Beyec J, Bouillot JL, Clement K, Czernichow S: Melanocortin-4 receptor mutations and polymorphisms do not affect weight loss after bariatric surgery. Plos One 2012; 7:e48221.

70 Elkhenini HF, New JP, Syed AA: Five-year outcome of bariatric surgery in a patient with melanocortin-4 receptor mutation. Clin Obes 2014;4:121-124.

71 Censani M, Conroy R, Deng L, Oberfield SE, McMahon DJ, Zitsman JL, Leibel RL, Chung WK, Fennoy I: Weight loss after bariatric surgery in morbidly obese adolescents with MC4R mutations. Obesity (Silver Spring) 2014; 22:225-231.

72 Aslan IR, Ranadive SA, Ersoy BA, Rogers SJ, Lustig RH, Vaisse C: Bariatric surgery in a patient with complete MC4R deficiency. Int J Obes 2011;35:457-461.

73 Ho AL, Sussman ES, Pendharkar AV, Azagury DE, Bohon C, Halpern CH: Deep brain stimulation for obesity: rationale and approach to trial design. Neurosurg Focus 2015;38:E8.

74 Wang XH, Wang HM, Zhao BL, Yu P, Fan ZC: Rescue of defective MC4R cell-surface expression and signaling by a novel pharmacoperone Ipsen 17. J Mol Endocrinol 2014;53:17-29.

75 Choquet H, Meyre D: Genomic insights into early-onset obesity. Genome Med 2010;2:36. 